\title{
A Cross-Sectional Study on Vocabulary Size Among Different Levels of the University Students
}

\author{
Annisa Shofa Tsuraya \\ annisa_tsuraya92@yahoo.com \\ Haryanto Atmowardoyo \\ haryanto@unm.ac.id \\ Universitas Negeri Makassar, Indonesia
}

\begin{abstract}
The objectives of this research were to know students' vocabulary size; and to know whether there was significant difference of vocabulary size among the students of different levels of English Education Department Faculty of Teacher Training and Education of Makassar Muhammadiyah University in academic year 2017/2018. This study used quantitative descriptive and cross-sectional study as the design of the study. The sample of this study were the first, third, fifth, and seventh semester students. The instrument of this study is a vocabulary size test. It used one-way ANOVA to analyze the data of the test. The findings reveal that the highest mean score was the seventh semester students and the lowest mean score was the third semester students. And the most beyond expectation was the mean score of the first semester students which gone over the third and fifth semester students' mean score. There is significant difference of the vocabulary size among the students of different levels. The result showed $\mathrm{F}$-value $\left(\mathrm{F}_{0}\right) 11.11$ is greater than F-table $\left(\mathrm{F}_{\mathrm{t}}\right)$ 2.60, $(11.11 \geq 2.60)$. Then the $\mathrm{p}$ value is 0.000 lower than $0.05(0.000 \leq 0.05)$. Hence, it can be concluded that $\mathrm{H}_{0}$ is rejected and $\mathrm{H}_{1}$ is accepted. Post Hoc Multiple Comparison showed that significant difference did not exist between some groups and only exist between two groups. Clearly, from the result, it can be said that there was significant difference of vocabulary size among the university students of different levels of English Department of Makassar Muhammadiyah University.
\end{abstract}

Keywords: cross-sectional study, vocabulary, vocabulary size test

\section{INTRODUCTION}

Nowadays, mostly reading texts in Indonesian school use authentic materials such as news paper, articles, novel, and so on which contains many vocabularies. Authentic materials are the materials which taken from students environments. If students do not know the meaning, it will affect their understanding and comprehension which relates to their academic achievement at school or university. That is way it is important to know their vocabulary size.

Vocabulary size can be defined as the number of words that a learner has in mental lexicon. Knowing students' vocabulary size not only help students improve their own self but also help teachers or lecturers motivate and teach them using good way to increase their vocabulary size. It can be measured using vocabulary size test.

According to Nation (2012) the vocabulary size test is designed to give an estimation of vocabulary size for second and foreign language learners of general or academic English. This vocabulary size has a relationship with the ability in using English in various ways. Vocabulary size measurement is important for planning, diagnosis and research. It is not 
easy to plan a sensible vocabulary development program without knowing where learners are now in their vocabulary growth (Nation \& Beglar: 2007).

Nation (2006) stated that research on the amount of vocabulary needed for receptive use indicate that learners need around 5,000 word families to read novels written for teenagers, to watch movies, and to participate in daily conversation, around 9,000 to 10,000 words are needed to read authentic materials, novels, and some academic texts. In other words, the standard of vocabulary size which has to be owned by the students for high school is about 5,000 words and 10,000 words for students at the university level.

Based on the illustration above, the objectives of this study were addressed to find out:

1. The vocabulary size of the students of English Department of Makassar Muhammadiyah University.

2. The significant difference of vocabulary size among the students of different levels of English Department of Makassar Muhammadiyah University.

\section{REVIEW OF LITERATURE}

There have been some studies on vocabulary size in the field of education. Milton and Treffers (2013) explained in their research article that vocabulary knowledge provides the essential building block of language and without vocabulary neither language production nor language comprehension is possible. The result of the test showed that universities students in British mostly have 10.000 words and just little figure of students have until 25.000 words even more. The largest mean vocabulary size is the monolingual English speakers, then the bilingual English speakers have a slightly smaller vocabulary size, and the speakers of English as a foreign language (EFL) have the smallest mean vocabulary size. And those means are statistically significant. The correlation between vocabulary size and reading habits are not statistically significant. Based on the result, the correlation between vocabulary size and academic performance are significant and suggest a modest connection between both.

Waldvogel (2013) in his study focused on the relationships between vocabulary learning strategies and vocabulary size among adult Spanish foreign language. He conducted the research in 475 college students enrolled in Spanish course whose their first language was English language. He took the learner for his subject of the study at the beginning, intermediate, and advance learner level. The result showed that there was a correlation between vocabulary learning strategy and vocabulary size in advance level while in basic and intermediate level the correlation was not significant. His research found that there were patterns in vocabulary learning strategy used by the learner in every level. Furthermore, the research proved that advance learner who gained the highest vocabulary size used more vocabulary learning strategies in their learning.

Coxhead, Nation, and Sim (2015) in their journal article which aimed to examine the vocabulary size of native speakers of English in New Zealand secondary schools. Two equivalent forms of the 20,000 version of the Vocabulary Size Test were used in this study. Two hundred and forty-three 13 to 18 year old native speakers of English at secondary school took an individually-administered version of the test.

Based on the theories above the writer concludes that vocabulary is the stock of words used to express thoughts, feelings and to communicate to other people both oral and written 
forms. The researcher proposes the difference among the mentioned researchers. This study focuses on vocabulary size among different levels of the university students.

\section{RESEARCH METHOD}

The design of this research was cross sectional research design by using developmental study. Atmowardoyo (2010: 80) explains that a developmental study is conducted to examine developmental differences or developmental change. Two different designs might be used to make inferences about change over time: cross-sectional design and longitudinal design. Cross-sectional design is chosen to investigate differences between or among participants that vary by age or grade. In addition, Gay et al. (2012) state that crosssectional research is one in which data are collected from selected individuals at a single point in time. This research was quantitative descriptive since the data gathered was in the form of number that intends to investigate whether there is a significant difference between the first, third, fifth, and seventh semester students in vocabulary size.

The sampling technique used in this research is random sampling. In this research, the samples were each one class of the first, third, fifth, and seventh semester of English Department of Makassar Muhammadiyah University in the Academic Year 2017/2018. The procedures were: the researcher took 10 students from 4 classes of each semester class. So, there were 40 students which chosen based on the forth fold number on students' presence list.

This research used vocabulary size test as the instrument. The vocabulary size test which used for measuring the participants' vocabulary size was adapted from Nation \& Beglar (2007). It is measuring written receptive vocabulary knowledge that is the vocabulary knowledge required for reading. It is not measuring listening vocabulary size, or the vocabulary knowledge needed for speaking and writing (Nation, 2012). This test was a multiple-choice format consisting of 100 items with 10 items from each 1000 word levels. The participants were invited to choose one correct answer that has similar meaning to the target word. The data collected from each class will be analyzed by using the statistical package for the social science (SPSS) version 22.00 for windows.

\section{FINDINGS AND DISCUSSION}

\section{The Vocabulary Size of the Students of English Department}

Based on the vocabulary size test result of the first, third, fifth, and seventh semester students of English Department Faculty of Teacher Training and Education Muhammadiyah University of Makassar could be seen that the mean score of first semester students' vocabulary size was 40.65 , the third semester students' vocabulary size was 35.275 , the fifth semester students' vocabulary size was 37.425 , and the seventh semester students' vocabulary size was 45.95 . Simply, it could be seen on the chart below. 


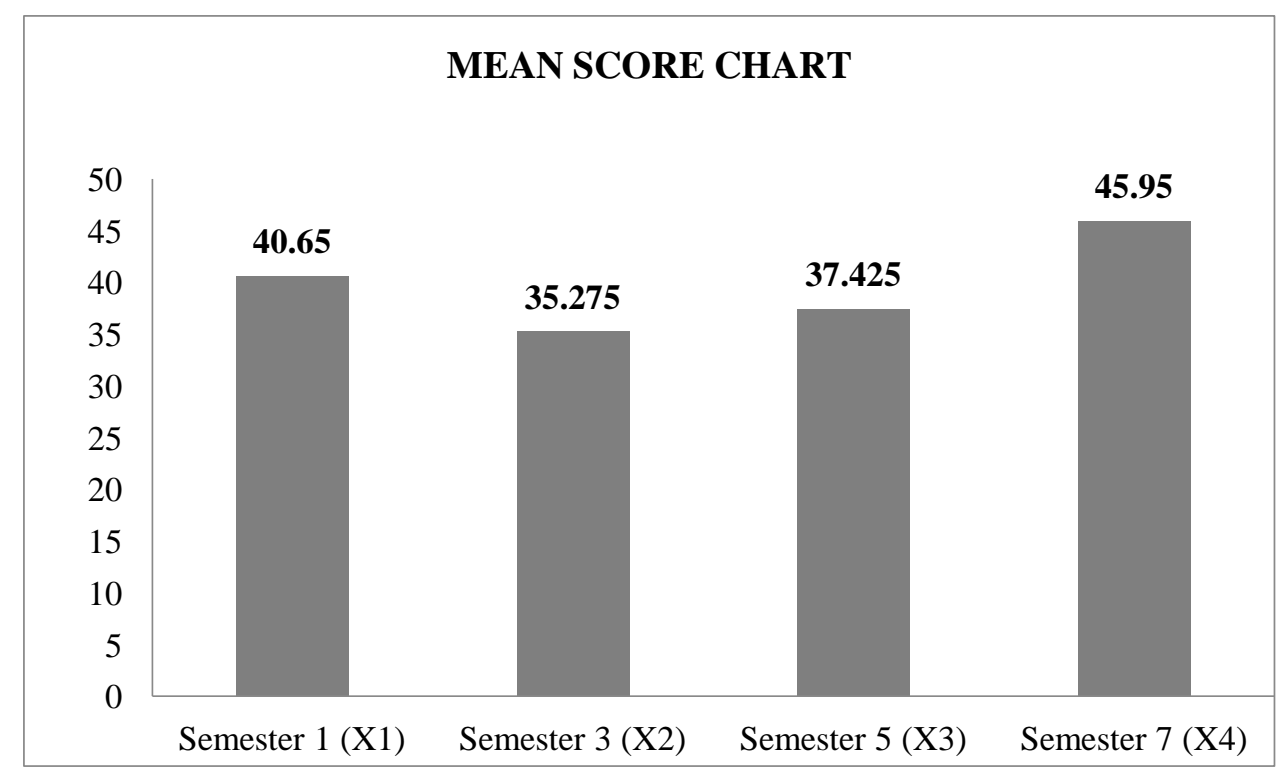

The mean score chart above showed that the highest mean score was the seventh semester students with 45.95 and the lowest mean score was the third semester students with 35.275. And the most beyond expectation was the mean score of the first semester students which got 40.65 gone over the third and fifth semester students' mean score.

Findings indicated that the first, third, fifth, and seventh semester students got almost the similar score with a little difference in their vocabulary size test. The differences may caused by some factors such as length of study, gender, age, and habit.

The vocabulary size test which consisted of 10 levels with 100 items of multiple choices measured written receptive vocabulary only that required for reading. So, it was not measuring listening vocabulary size, or the vocabulary knowledge needed for speaking and writing. The vocabulary size test related to 3 main frequency levels, they were low frequency, mid frequency, and high frequency words.

For the low frequency words, it was on first until fourth 1000 levels of the test. It contained familiar words that can be seen in daily reading text like children short story. Then, mid frequency words were on the fifth until seventh 1000 levels of the test. The level of this word was higher than low frequency words. It could be seen in authentic reading text like newspaper. And the high low frequency words were on the eighth until tenth 1000 levels of the test. The words were very rare to be seen in daily reading text. It can be seen in journal article and academic text.

Each semester showed different result of vocabulary size test even though the test instrument which used was same for all semester level. Since this research used crosssectional study as research design so it will compare students' developmental difference rather than developmental changes.

The test result showed that seventh semester students had higher mean score than third and fifth semester students. But, the beyond expectation was the first semester students which had higher mean score of vocabulary size test than third and fifth semester students. The 
lowest mean score of vocabulary size test was third semester students. This result was in line with Fox and Birren (1949) in their research article that there was no relation between vocabulary size and either length of institutionalization, there was only a low positive correlation between vocabulary and years of education.

The samples consisted of males and females students. But the range score between males and females not too far, it would be rather similar each other. Thereby, it can be concluded that there was no significant difference of vocabulary size in gender differences, as it stated by Coxhead, Nation, and Sim (2015) in their research that there were no gender differences in vocabulary size.

Referred to the results that the first semester students which had higher mean score of vocabulary size test than third and fifth semester students the researcher guess that first semester students as the younger age students has higher motivation in learning English than third and fifth semester students as the older age students. It was also found by Catalan and Gallego (2008) that younger students may be more motivated in the learning of foreign language than older students and that motivation may be positively related to vocabulary size.

The findings of the research showed that the means and ranges of vocabulary size across length of study, gender differences, age differences and habit reveal that even the learners with the smallest vocabulary sizes know many thousands of words and know a large part of the high-frequency and mid-frequency words of English.

\section{Significant Differences in Vocabulary Size among the Students of Different Levels}

After the result of descriptive statistic, another step of this study is continuing to conduct the inferential statistic for hypothesis testing. It was conducted to know whether there were or not significant differences of vocabulary size of students among different levels. In testing the hypothesis was used One-Way ANOVA. The first, third, fifth, and seventh semester students were compared by vocabulary size test score. The result is reported on the following table:

\section{ANOVA}

Vocabulary Size Score

\begin{tabular}{|l|r|r|r|r|r|}
\hline & Sum of Squares & df & Mean Square & F & Sig. \\
\hline Between Groups & 2586.350 & 3 & 862.117 & 11.11 & .000 \\
Within Groups & 12100.750 & 156 & 77.569 & & \\
Total & 14687.100 & 159 & & & \\
\hline
\end{tabular}

The table ANOVA above reported that the result of sum of squares, degree of freedom (df), mean square, F-value, and significance score of between groups, within groups and total score. The result above show whether there is differences or not could be recognized from the result of F-value $(3,156)$ which was 11.11 and F-table $(\mathrm{Ft})$ was 2.60. 
The result showed that F-value $\left(\mathrm{F}_{\mathrm{o}}\right) 11.11$ is greater than F-table $(\mathrm{Ft}) 2.60,(11.11 \geq 2.60)$. Then the $p$ value was 0.000 lower than $0.05(0.000 \leq 0.05)$. Hence, it can be concluded that $\mathrm{H}_{0}$ is rejected and $\mathrm{H}_{1}$ is accepted. Clearly, from the result, it can be said that there was significant difference of vocabulary size among the university students of different levels of English Department of Makassar Muhammadiyah University.

Moreover, Post-Hoc test is conducted to show the specific data of there is significant difference of vocabulary size among the students of different levels. Post-Hoc procedures of testing used Scheffé Test. That was the testing procedure of Post-Hoc that most often to be used for detail information of the data comparison. Post-Hoc test presented on the following table:

\section{Post Hoc Test Multiple Comparisons}

Dependent Variable: Vocabulary Size Test Scheffé Test

\begin{tabular}{|ll|r|r|r|r|r|}
\hline \multirow{2}{*}{ (I) Semester } & & \multicolumn{1}{c|}{$\begin{array}{c}\text { Mean } \\
\text { (J) Semester }\end{array}$} & $\begin{array}{c}\text { Difference } \\
\text { (I-J) }\end{array}$ & Std. Error & Sig. & \multicolumn{2}{|c|}{ 95\% Confidence Interval } \\
\cline { 6 - 7 } & & & Lower Bound & Upper Bound \\
\hline Semester 1 & Semester 3 & 5.3750 & 1.9694 & .063 & -.191 & 10.941 \\
& Semester 5 & 3.2250 & 1.9694 & .446 & -2.341 & 8.791 \\
& Semester 7 & -5.3000 & 1.9694 & .069 & -10.866 & .266 \\
\hline Semester 3 & Semester 1 & -5.3750 & 1.9694 & .063 & -10.941 & .191 \\
& Semester 5 & -2.1500 & 1.9694 & .755 & -7.716 & 3.416 \\
& Semester 7 & $-10.6750 *$ & 1.9694 & .000 & -16.241 & -5.109 \\
\hline Semester 5 & Semester 1 & -3.2250 & 1.9694 & .446 & -8.791 & 2.341 \\
& Semester 3 & 2.1500 & 1.9694 & .755 & -3.416 & 7.716 \\
& Semester 7 & $-8.5250 *$ & 1.9694 & .000 & -14.091 & -2.959 \\
\hline Semester 7 & Semester 1 & 5.3000 & 1.9694 & .069 & -.266 & 10.866 \\
& Semester 3 & $10.6750 *$ & 1.9694 & .000 & 5.109 & 16.241 \\
& Semester 5 & $8.5250 *$ & 1.9694 & .000 & 2.959 & 14.091 \\
\hline
\end{tabular}

$*$. The mean difference is significant at the 0.05 level.

The Post-Hoc multiple comparisons showed that there were two group that has significant differences of vocabulary size because the data clearly reported that their significant value were lower than 0.05 , while others were not because their significant value were greater than 0.05 . The probability to have the significant difference, the sig, value or significance value should lower than 0.05 .

Based on the table Post Hoc Multiple Comparisons Scheffé Test above, it can be seen that significant difference did not exist between some groups and only exist between two groups. There was no significant difference exist between first $\left(\mathrm{X}_{1}\right)$ and third $\left(\mathrm{X}_{2}\right)$ semester students $(0.063 \geq 0.05)$, it meant that null hypothesis $\left(\mathrm{H}_{0}\right)$ was accepted and alternative hypothesis $\left(\mathrm{H}_{\mathrm{a}}\right)$ was rejected. It also happened between first $\left(\mathrm{X}_{1}\right)$ and fifth $\left(\mathrm{X}_{3}\right)$ semester students $(0.446 \geq 0.05)$, it meant that null hypothesis $\left(\mathrm{H}_{0}\right)$ was accepted and alternative hypothesis $\left(\mathrm{H}_{\mathrm{a}}\right)$ was rejected. So did the first $\left(\mathrm{X}_{1}\right)$ and seventh $\left(\mathrm{X}_{4}\right)$ semester students $(0.069 \geq 0.05)$, it meant that null hypothesis $\left(\mathrm{H}_{0}\right)$ was accepted and alternative hypothesis 
$\left(\mathrm{H}_{\mathrm{a}}\right)$ was rejected. And third $\left(\mathrm{X}_{2}\right)$ and fifth $\left(\mathrm{X}_{3}\right)$ semester students $(0.755 \geq 0.05)$, it meant that null hypothesis $\left(\mathrm{H}_{0}\right)$ was accepted and alternative hypothesis $\left(\mathrm{H}_{\mathrm{a}}\right)$ was rejected. While there were significant difference exist between third $\left(\mathrm{X}_{2}\right)$ and seventh $\left(\mathrm{X}_{4}\right)$ semester students $(0.000 \leq 0.05)$ and fifth $\left(X_{3}\right)$ and seventh $\left(X_{4}\right)$ semester students $(0.000 \leq 0.05)$, it meant that null hypothesis $\left(\mathrm{H}_{0}\right)$ was rejected and alternative hypothesis $\left(\mathrm{H}_{\mathrm{a}}\right)$ was accepted. The first group was first semester students that would to be compared with other groups. There was no significant difference exist between first and third semester students even though the first semester students' mean score of vocabulary size test higher than third semester students'. So that first and fifth semester students, there was no significant difference between them even though the first semester students' mean score of vocabulary size test higher than fifth semester students'. And also between first and seventh semester students, there was no significant difference existed between them though first semester students' mean score was lower than seventh semester students'.

The second group was third semester students that would be compared with others groups. There was no significant difference existed between third and fifth semester students where third semester students' mean score was lower than fifth semester students'. But, there was significant difference existed between third and seventh semester students with far range mean score. The mean score of third semester students was very lower than seventh semester students'. It was the lowest mean score of vocabulary size test.

The third group was fifth semester student that would be compared with the fourth group that was seventh semester students. There was significant difference exist between them where the mean score of fifth semester students was lower than seventh semester students'.

According to Nation (2006) in his research journal that the learners need around 6,000 words to read novels written for teenager, to watch movies, and to participate in friendly conversation. Around 8,000 to 10,000 words are needed to read news paper, novels, and some academic text. Meanwhile, the test result proved that the average number of students' vocabulary size was not more than 5,000 words which did not reach the standard of university level that is 10,000 words.

The researcher assumed that it was normally that Indonesian learners had lower vocabulary size because in Indonesia English language is as the foreign language. This assumption was in line with Milton and Dallers (2013) in their research that the result of the test shows that universities students in British mostly have 10.000 words and just little figure of students have until 25.000 words even more. The largest mean vocabulary size is the monolingual English speaker, then the bilingual English speakers have a slightly smaller vocabulary size and the speakers of English as a foreign language (EFL) have the smallest mean vocabulary size.

Milton and Dallers (2013) as found in their research mentioned that there was significant difference between vocabulary size and students' achievement in the university. While conducting the vocabulary size test, the researcher also asked to students one by one about their obstacles in learning English. And mostly students felt difficult in learning English (reading, listening, speaking, and writing) caused by the lack of vocabulary.

Through this research, students realized that they were still need many vocabularies and knew the solution of their lack of vocabulary problem and the appropriate learning strategies to increase their vocabulary size. The lecturers also could decide the best and 
appropriate way in teaching English in order students could increase their number of vocabulary size.

\section{CONCLUSION}

This research investigates the students' vocabulary size and the significant difference of vocabulary size among students of different levels of English Department. Cross sectional developmental study was used as research design of this research.

The findings of the study showed that the highest mean score of vocabulary size test score was seventh semester students. While the lowest means score of vocabulary size test score was third semester students. Moreover, mean score of vocabulary size test score of first semester students was higher than third and fifth semester students.

Post Hoc Multiple Comparison Scheffé Test showed that $\mathrm{H}_{0}$ is rejected and $\mathrm{H}_{1}$ is accepted. It means that there is significant difference of vocabulary size among the students of different levels. The significant differences existed among the third, fifth, and seventh semester students. The third and seventh semester students had significant difference in the vocabulary size and also the fifth and seventh semester students.

The findings of the research showed that even the learners with the smallest vocabulary sizes know many thousands of words and know a large proportion of the high-frequency and mid-frequency words of English.

\section{REFERENCES}

Atmowardoyo, H. (2010). Research Method for Language and Literature Studies. Makassar: Badan Penerbit Universitas Negerin Makassar

Catalán, R. M. J., \& Gallego, M. T. (2008). The Receptive Vocabulary of English Foreign Language Young Learners. Journal of English Studies, (5), 173-192.

Coxhead, A., Nation, I. S. P., \& Sim, D. (2015). Measuring the Vocabulary Size of Native Speakers of English in New Zealand Secondary School. New Zealand Journal of Educational Studies. 50(1): 121-135.

Coxhead, Averil. (2000). A New Academic Word List. TESOL Quarterly. 34: 213-238.

Fox, C., \& Birren, J. E. 1949. Some Factors Affecting Vocabulary Size in Later Maturity: Age, education, and Length of Institutionalization. Journal of Gerontology, 4(1), 19-26.

Gay, L. R., Mills, G. E., Airasian, P. W. (2012). Educational Research: Competencies for Analysis and Application. United States of America: Pearson Education, Inc.

Milton, J., \& Treffers-Daller, J. (2013). Vocabulary Size Revisited: The Link between Vocabulary Size and Academic Achievement. Applied Linguistics Review, 4(1), 151-172.

Nation, I. S. P. (2001). Learning Vocabulary in Another Language. Cambridge: Cambridge University Press.

Nation, I. S. P. (2006). How Large a Vocabulary is needed for Reading and Listening? Canadian Modern Language Review. 63(1): 59-82.

Nation, I. S. P. (2012). Measuring Vocabulary Size in an Uncommonly Taught Language. International Conference on Language Proficiency Testing in the Less Commonly Taught Languages. 
72 ELT Worldwide Vol. 5 No. 1 (2018)

Tsuraya, Atmowardoyo: A Cross-Sectional Study on ...

Nation, P., \& Beglar, D. (2007). A Vocabulary Size Test. The Language Teacher. 31(7): 913.

Waldgovel, D.A. (2013). The Relationship between Vocabulary Learning Strategies and Vocabulary Size among Adult Spanish Foreign Language Learners. Journal of Language Teaching and Research. 4(2): 209-219. 